\title{
Prevalence and risk of potentially adverse drug interactions in the treatment of acute alcohol poisoning
}

\author{
Joyce Dalline Silva Andrade 1 , Chiara Erminia Rocha², Maria Amélia Vieira Maciel ${ }^{3}$, Danielle \\ Cristine Almeida Silva de Santana ${ }^{4}$, Fernando José Malagueño de Santana ${ }^{1,4, *}$
}

${ }^{1}$ Pharmacy Department of São Cristóvão, Federal University of Sergipe, Aracaju, SE, Brazil, ${ }^{2}$ Pharmacy Department of Lagarto, Federal University of Sergipe, Lagarto, SE, Brazil, ${ }^{3}$ Tropical Medicine Department, Federal University of Pernambuco, Recife, PE, Brazil, ${ }^{4}$ Pharmaceutical Sciences Department, Federal University of Pernambuco, Recife, PE, Brazil

\begin{abstract}
The aim of this paper is to determine the profile of acute alcohol poisoning and to estimate the risk of potentially adverse drug interactions (ADIs) in patients intoxicated by alcohol when attended in emergency care at hospital. A descriptive serial cross-sectional study was performed with 4,271 individuals intoxicated by alcohol, from January 2009 to July 2011. Possible correlations were measured by Pearson's chi-square test. The data show high consumption in the population, especially in males between 25 and 59 years. The main circumstances for poisoning were alcohol misuse (96.3\%). After treatment complete recovery from the signs or symptoms of the poisoning was observed in $96.88 \%$ cases; and death in $0.70 \%$. The demonstration of potential risk for ADIs in medical care included 300 medical records which contained a history of acute alcohol poisoning. Possible drug-drug interactions (44.2\%) and drug-alcohol interactions $(55.8 \%)$ were demonstrated in $60.60 \%$ of analyzed medical records. Among these cases, 3\%, 92.4\% and $4.6 \%$ were classified as mild, moderate and severe, respectively. The measurement of ADIs aims to prevent clinical complications in medical care for alcohol misuse disorders.
\end{abstract}

Uniterms: Alcoholic intoxication. Emergency Medical Services. Risk Management. Medicines/adverse interactions/risk control. Medicines/alcohol interactions/risk control.

O objetivo deste trabalho foi definir o perfil de intoxicação alcoólica aguda e estimar o risco de interações medicamentosas adversas (IMAs) potenciais em pacientes com intoxicação alcoólica atendidos na emergência hospitalar. Um estudo descritivo, serial, de corte transversal foi realizado com 4.271 indivíduos com intoxicação alcoólica, de janeiro 2009 a julho 2011. Correlações foram medidas pelo teste qui-quadrado. Os dados mostram alto consumo na população estudada, especialmente em homens de 25 a 59 anos. A principal circunstância de intoxicação foi o abuso (96,3\%). Após tratamento, cura foi observada em $96,88 \%$ dos casos e morte em $0,7 \%$. O risco de IMAs potenciais no atendimento médico incluiu 300 prontuários médicos com histórico de intoxicação alcoólica aguda. Possíveis interações medicamentosas $(44,2 \%)$ e interações fármaco-álcool (55,8\%) foram observadas em 60,6\% dos prontuários analisados. Entre elas, 3\%, 92,4\% e 4,6\% foram classificadas como leve, moderada e grave, respectivamente. A medição das IMAs visa a prevenir complicações clínicas no atendimento dos agravos devido ao abuso de álcool.

Unitermos: Intoxicação alcoólica. Serviços Médicos de Emergência. Medicamentos/interações adversas/ controle de risco. Medicamentos/interação com álcool/controle de risco.

*Correspondence: F. J. M. de Santana. Departamento de Ciências Farmacêuticas. Universidade Federal de Pernambuco. Av. Professor Artur de Sá, 50740-521 - Recife, PE. E-mail: fmalagueno@hotmail.com 


\section{INTRODUCTION}

In Brazil, poisoning cases are continuously reported to the State Poisoning Information Centers (CIATOX), members of the National Poisoning Information System (SINITOX).

The center is a specialized unit that provides information, guidance and advice on the diagnosis, prognosis and management of the poisoned patient, as well as promoting the prevention of poisoning for the whole medical and non-medical community. According to the CIATOX of the state of Sergipe (SE), in the Northeast of Brazil, alcohol played its role in $39.30 \%$ of Brazil's poisoning cases by drug misuse, as reported in 2011 (SINITOX, 2011).

Acute poisoning is the common cause for entry into hospital emergency department (ED) admissions worldwide. The World Health Organization (WHO) estimates that $50 \%$ of alcohol-related injuries are attributable to acute poisonings and the other $50 \%$ to chronic alcohol consumption (Ye, Cherpitel, 2009).

These intoxications exclude alcoholics, or those consumers at risk of harm, and include those who have suffered some health damage by periodic heavy ("binge") alcohol drinking (Roizen, 2009). Excessive alcohol consumption is a common social practice, often resulting in a set of physical and mental disorders (loss of inhibition, cognitive impairment, decreased attention span, a worsening of judgment, impaired motor coordination, irritability, etc.). These events cause unwanted consequences not only to those who are intoxicated but also to society, in all countries. Some studies have come to suggest that sporadic binge drinking can cause more social and health damage than continuous use (Naimi et al., 2003; Segatto et al., 2007).

The hazardous alcohol-injury association caused by episodic, acute alcohol consumption - from the intentions to commit violence and attempt suicide to unintentional consequences (isolated accidents) - is of growing concern to Health Agencies around the world (Naimi et al., 2003).

Regardless of how these exposures of the problem occur, through acute or chronic intake, medical attention for alcohol-related deaths (cirrhosis, some cancers, cerebral stroke, mental disorders, loss of consciousness, respiratory depression, apnea and coma) is highly costly and unyielding. In severe cases, drinking alcohol may cause permanent physiological disorders or even death (Schuckit, 2011).

Adverse drug events (ADEs) are common and expensive for medicine. In ED, ADEs are an important and recognized cause of medical errors related to drugs
(Vonbach et al., 2008; Bates et al., 1997).

Among the ADE risk factors, adverse drug interactions (ADIs) resulting from inappropriate prescribing of drugs in emergency rooms may endanger hospitalized patients' health. Therefore, these interactions deserve special attention (Heininger-Rothbucher et al., 2001). Inducing the potential risk of ADIs, co-prescription of multiple drugs in order to improve the effectiveness of the treatment regime, to reduce toxicity, or to treat coexisting diseases, is a common strategy in hospitals, including the emergency department (Bosch et al., 2012).

Historically, alcohol use is often associated with several legal or illegal drugs of abuse (commonly by teens) and can have serious consequences, such as those resulting from adverse drug-alcohol interactions (Gudin et al., 2013). Research on ADIs with drugs of abuse in emergency departments has not become routine. However, many adverse effects and deaths that are attributed to drug abuse toxicity alone are, often, actually the result of drug interactions.

This study aims to describe the acute alcohol poisoning patient's profile, attended in ED and reported to CIATOX-SE; as well as to estimate the prevalence and gravity of ADIs in emergency hospital-medical care of these patients.

\section{METHOD}

This is a descriptive and retrospective serial crosssectional regional study conducted for a population of 4,271 patients intoxicated by alcohol, from January 2009 to July 2011.

The data for this population was collected from the CIATOX-SE database. This unit is located at the main emergency hospital of Sergipe (HUSE), in the state capital (Aracaju), and it is the state's benchmark in emergency services for poisoning.

The sample included all patients diagnosed as F10.0 according to the International Classification of Diseases and Related Health Problems, 10th Revision (ICD-10). F10.0 refers to mental and behavioral disorders caused by the use of alcohol - acute intoxication (WHO, 2010). These patients were attended in the EDs of the main hospitals located in Aracaju's metropolitan area; and their medical records information was reported to CIATOX-SE.

The independent variables were: gender, age, geographical area of residence, origin of place, circumstances of poisoning, type of exposure, length of hospital stay and medical care outcome.

The drugs used in emergency hospital-medical care, length of hospital stay information, as well as the patient's 
legal and/or illegal drug abuse associated with alcohol consumption, were collected from the medical records of a representative sample of patients intoxicated by alcohol. These records were supplied by the Hospital Statistics Department and Medical Archive (SAME/HUSE) and were used to analyze the potential risk of ADIs occurring in the acute alcohol poisoning cases attended in ED.

The representative sample was calculated considering the prevalence of patients intoxicated by alcohol over the total of individuals intoxicated by drug abuse and reported to the CIATOX-SE during the study period.

A $5 \%$ margin of error (95\% confidence interval) was adopted. The sample size was calculated by simple random sampling and 300 medical records were selected and analyzed for the potential risk of ADIs.

Medical records that were erased, illegible, inaccessible, and/or belonging to transferred patients (who during the emergency hospital-medical care were transferred to another hospital) were excluded from the sample.

Adverse drug-drug and drug-alcohol interactions were assessed by computer software. The level of significance for interaction (severe, moderate and mild) was classified according to Drug.com ${ }^{\circledR}$ database - a computerized drug-drug interaction (DDI) screening program. Drug.com ${ }^{\circledR}$ compiles medical information from: Wolters Kluwer Health ${ }^{\mathrm{TM}}$, the American Society of HealthSystem Pharmacists $^{\mathrm{TM}}$, Cerner Multum ${ }^{\mathrm{TM}}$ and Thomson Reuters Micromedex ${ }^{\mathrm{TM}}$ databases (Drug Interactions Checker: <http://www.drugs.com/drug_interactions. html).

All statistical analyses were performed using the Epi Info program version 3.3 for Windows. Data were showed as mean (M), standard deviation (SD), absolute frequency (n) and relative frequency (\%). The relationship between poisoning circumstances and age was established using the Pearson chi-square test $\left(\mathrm{x}^{2}\right)$. P values less than 0.05 are reported as statistically significant.

This study was approved by both the Ethics Committee of the Federal University of Sergipe (CEP $n^{\circ} 370 / 2011$ and CAAE $n^{\circ}$ 0332.0.107.000-11) and the Continuing Education Center of the HUSE hospital complex.

\section{RESULTS AND DISCUSSION}

During the study period, 15,818 acute cases of intoxication by drug abuse occurred. Alcohol had the highest prevalence $(27.30 \%)$ among all toxic agents involved. This high prevalence was expected since in accordance with the United Nations Office on Drugs and Crime (UNODC), alcohol is the most widely consumed licit psychoactive substance in the world (UNODC, 2013).

TABLE I - Distribution of independent variables: gender, age, geographical area of residence, place of origin, circumstances of poisoning, type of exposure and medical care outcome in 4,271 cases of acute alcohol poisoning. Sergipe, January 2009 to July 2011

\begin{tabular}{|c|c|c|}
\hline Variables & $\mathrm{AF}^{\mathrm{a}}(\mathrm{n})$ & $\mathrm{RF}^{\mathrm{b}}(\%)$ \\
\hline \multicolumn{3}{|l|}{ Gender } \\
\hline Men & 3,793 & 88.81 \\
\hline Women & 478 & 11.19 \\
\hline Total & 4,271 & 00 \\
\hline \multicolumn{3}{|l|}{ Age group (yrs.) } \\
\hline $01-11$ & 5 & 0.12 \\
\hline $12 \dashv 17$ & 89 & 2.08 \\
\hline $18 \dashv 24$ & 530 & 12.41 \\
\hline $25 \dashv 34$ & 1,038 & 24.31 \\
\hline $35-44$ & 1,134 & 26.56 \\
\hline $45-59$ & 1,116 & 26.12 \\
\hline $60+$ & 216 & 5.05 \\
\hline $\mathrm{U}^{*}$ & 143 & 3.35 \\
\hline Total & 4,271 & 100 \\
\hline \multicolumn{3}{|l|}{ Place of Origin } \\
\hline Capital city & 2,708 & 63.41 \\
\hline Neighboring cities & 1,563 & 36.59 \\
\hline Total & 4,271 & 100 \\
\hline \multicolumn{3}{|l|}{ Geographical Area } \\
\hline Urban & 4,090 & 95.78 \\
\hline Rural & 173 & 4.06 \\
\hline $\mathrm{U}^{*}$ & 7 & 0.16 \\
\hline Total & 4,271 & 100 \\
\hline \multicolumn{3}{|l|}{ Circumstance } \\
\hline Abuse (misuse) & 4,113 & 96.30 \\
\hline Accidental & 101 & 2.36 \\
\hline $\mathrm{U}^{*}$ & 57 & 1.34 \\
\hline Total & 4,271 & 100 \\
\hline \multicolumn{3}{|c|}{ Medical care outcome } \\
\hline Cured & 4,138 & 96.88 \\
\hline Death & 30 & 0.70 \\
\hline Not specified & 103 & 2.42 \\
\hline Total & 4,271 & 100 \\
\hline
\end{tabular}

$\mathrm{AF}^{\mathrm{a}}$, Absolute Frequency (n); $\mathrm{RF}^{\mathrm{b}}$, Relative Frequency (\%). U, Uninformed. 
The acute alcohol poisoning profile is described in Table I.

The mean population was 37 years of age on average $( \pm 11)$; higher alcohol consumption was observed predominantly in the economically active population (ranging from 25 to 59 years of age).

Although not statistically significant, elderly individuals (age $\geq 60$ years old) accounted for $5.05 \%$ of acute alcohol poisoning cases. Nonetheless, this is a worrisome result because these individuals usually have a longer hospital stay due to severe injuries directly and/ or indirectly associated with alcohol. Furthermore, studies have shown that the need for co-administration of five or more drugs increases the potential risk of ADI in elderly patients intoxicated by alcohol (Mallet, Spinewine, Huang, 2007; Fulton, Allen, 2005).

The sample size included 3,793 men and 478 women, in an 8:1 ratio. This great difference can be explained considering both physiological processes and socio-cultural aspects.

Studies have demonstrated a higher alcohol blood concentration in women than in men after drinking the same amount of alcohol. Women consuming a smaller amount of alcohol than men will have similar psychoactive reactions. The differences in the effects on gender can be explained when considering alcohol's distribution in the human body - in terms of metabolism - in the bodies of men and women. Compared to men, women usually have smaller volumes of water in their body when alcohol is distributed. Besides, they have a less efficient first passive recovery in their metabolism when alcohol is involved, leading to greater absorption of alcohol directly into the bloodstream (Dettling et al., 2008; Nanchahal, Ashton, Wood, 2000; Wilsnack et al., 2000).

Some authors also suggest that gender difference in alcohol consumption depends on the type of alcoholic beverage (wine, beer, and others) most consumed in each group. Furthermore, it depends on how each society faces the role of drinking for men and women (Miller, Plant, Plant, 2005). The prevalence of beer among the Brazilian population partly explains the higher incidence of acute alcohol poisoning in the young men observed in our study. Needless to say, women have an important moral and conservative role in family life, and in social life, in a good number of both developed and developing countries (Wilsnack et al., 2000).

Regarding the geographical area of residence and place of origin of the population under study, it is important to mention that the CIATOX-SE conducts active surveillance for intoxication cases only in hospitals located in the metropolitan area of Aracaju (i.e., Hospital São José, Hospital João Alves, Urgência Fernando Franco Hospital,
Municipal Doutor Nestor Piva Hospital). Medical records of hospitals located in neighboring cities were not included. Under this condition, $63.41 \%$ of individuals resided in the state capital and $95.78 \%$ of individuals came from urban areas.

Despite the investigation being apparently restricted to urban areas and this possibly being a limitation of the study, we must consider that the land area of Sergipe State is the smallest of Brazil $\left(21,915,116 \mathrm{~km}^{2}\right)$ and that $73.5 \%$ of the state's inhabitants reside in urban areas. In addition, the metropolitan region of Aracaju (i.e., Aracaju, Barra dos Coqueiros, Nossa Senhora do Socorro, São Cristóvão) is the most populous area in the state with 899,239 inhabitants $(59.1 \%$ of the State's inhabitants) (IBGE, 2014).

According to Table I, alcohol abuse accounted for almost all cases of acute drug-related poisoning. This circumstance is alarming since alcohol abuse is a major cause of road traffic complications and accidents, causing death and injury around the world, including in Brazil (Lukens et al., 2006). Episodes of alcohol abuse are also associated with higher risks of violent acts, including murder, sexual offenses and family violence (Rehm et al., 1999). In England, a study showed that $42 \%$ of homicides between 1996 and 1999 involved the use of alcohol and illicit drug use by the perpetrator and/or victim (Shaw et al., 2006).

Our results show that in most cases, the length of the hospital stay was less than or equal to one day. Only $6.70 \%$ patients remained hospitalized longer than one day. After medical care, healing was observed in $96.88 \%$ patients and $0.70 \%$ cases led to death. Although mortality was not numerically representative (only 30 cases) it must be viewed with concern since according to the Brazilian Health Agency, acute alcohol poisoning is considered a transient phenomenon with complete recovery, except when complications arise in hospital-medical care (American Psychiatric Association, 2006).

Table II describes the relationship between alcohol intoxication circumstances and age group.

Although not statistically significant, the misuse of alcohol in children and adolescents is an alert for easy and frequent access of young people to alcohol. This is also an alert for the Children and Adolescents Law in Brazilian $\left(n^{\circ} .8069 / 9\right.$, art. 243), which prohibits the sale of alcoholic beverages to anyone under the age of 18 (Brazil, 2004).

Besides determining the profile of alcohol poisoning (risk group), the last aim of this study was to estimate the potential risk of ADIs in emergency hospital-medical care of these groups to improve their clinical outcome.

In hospital-medical care there were prescribed 
TABLE II - Relationship between independent variables: circumstances of alcohol abuse and age. Sergipe. January 2009 to July 2011

\begin{tabular}{lcccccc}
\hline $\begin{array}{l}\text { Circumstance } \\
\text { Age group (yrs.) }\end{array}$ & $\mathbf{A F}^{\mathbf{a}}$ & $\mathbf{R F}^{\mathbf{b}} \mathbf{( \% )}$ & $\mathbf{A F}^{\mathbf{a}}$ & $\mathbf{R F}^{\mathbf{b}} \mathbf{( \% )}$ & \multirow{2}{*}{ *** $\mathbf{U}$} & \multirow{2}{*}{ Total } \\
\hline $01-11$ & 5 & 0.12 & 0 & 0 & & 5 \\
$12 \dashv 17$ & 85 & 2 & 3 & 0.07 & 1 & 89 \\
$18 \dashv 24$ & 510 & 12 & 17 & 0.40 & 3 & 530 \\
$25 \dashv 34$ & 1,009 & 23.62 & 16 & 0.37 & 13 & 1,038 \\
$35 \dashv 44$ & 1,102 & 25.80 & 20 & 0.46 & 12 & 1,134 \\
$45-59$ & 1,092 & $25.56 \%$ & 16 & 0.40 & 8 & 1,116 \\
$60+$ & 212 & $4.90 \%$ & 2 & $0.04 \%$ & 2 & 216 \\
$* * * \mathrm{U}$ & 98 & $2.30 \%$ & 27 & $0.60 \%$ & 18 & 143 \\
Total & 4,113 & $96.30 \%$ & 101 & $2.34 \%$ & 57 & 4,271 \\
\hline
\end{tabular}

$p>0.05 . \mathrm{AF}^{\mathrm{a}}$, Absolute Frequency (n); $\mathrm{RF}^{\mathrm{b}}$, Relative Frequency (\%). *Abuse, intentional drinking to excess, **Accidental, unintentional alcohol intoxication, ${ }^{* * *} \mathrm{U}$, Uninformed; ${ }^{* *} \mathrm{P}$, Pearson's chi-square test $\left(\mathrm{x}^{2}\right)$.

$3.2( \pm 2.16)$ drugs per patient and the potential risk of ADIs was observed in $182(60.60 \%)$ prescriptions. In the pharmacotherapy of these individuals, about 52 pharmaceutical of the applications prescribed demonstrated $77 \%$ of potential risk of ADIs.

In our study a total of 496 possible interactions were identified, of which 197 (44.22\%) were classified as drug-drug interactions. Consequently, the population under study showed a high risk of potential for the therapy not being effective and/or clinical injuries in emergency hospital-medical care.

Because of the large number of co-administered drugs in hospital-medical care and the complexity of the drug interactions, some authors argue that a suitable characterization and control of every possible interaction for medical records is technically unfeasible. Therefore, the team dedicated to the well-being of the patient should focus its attention preferentially on those drugs which are used more frequently and show a higher potential risk of ADI, without disregarding other interactions (Hussar, 2000).

Among the major drugs described in our study, diazepam, phenytoin, metoclopramide and promethazine were involved in over half of the potential risk of ADIs (64.55\%). Metoclopramide, promethazine, and tramadol were involved in over $92 \%$ possible ADIs. Therefore, co-administration of these drugs requires a suitable risk management, and rigorous patient care, in order to avoid adverse reactions and/or therapeutic ineffectiveness.

Moderate risk of ADIs was observed in $92.40 \%$ of cases. This may induce clinical deterioration in patients and require additional medical care, or increase the length of the hospital stay. Severe risks of ADIs have proved to be less frequent (4.60\%). These are very dangerous and may promote permanent adverse effects in patients. Thus, co-prescription of drugs involved in moderate or severe ADI cases should be vigorously avoided.

Mild ADI cases require patients' monitoring, are less of a problem, and may induce some discomfort. This disturbance is onerous for hospital-medical care (Hussar, 2000).

Although metoclopramide (an antiemetic drug) has been widely used in alcohol poisoning treatment, being the most frequently drug used (10.38\%), it entails moderate and severe potential risk of ADIs (Table III).

Metoclopramide and scopolamine (antispasmodic drug) co-administration had the highest frequency of drug association observed by our study. This association of drugs showed moderate ADI gravity, reducing the action of metoclopramide and requiring dose adjustment for the effective treatment of patients (Hussar, 2000).

Other moderate and severe ADIs were described in Table III. Brief comments on the reasons for the administration of each drug in the pharmacotherapy of alcohol intoxication treatment are also included in Tables III and IV (Carlson et al., 2012). The few unwanted events resulting from these associations may have contributed to the cases of death previously described in our research. However, other studies must be done to confirm this hypothesis.

Besides the potential risk of ADIs between drugs used in alcohol poisoning treatment, alcohol itself can also be interacting with drugs prescribed to hospital-medical care of these patients. In our study there were identified 299 (55.78\%) drug-alcohol interactions.

These possible interactions may occur through 
TABLE III - Gravity, frequency, interactions, and possible adverse reactions of potential drug-drug interactions in acute alcohol intoxication for hospital emergencies. Sergipe, January 2009 to July 2011

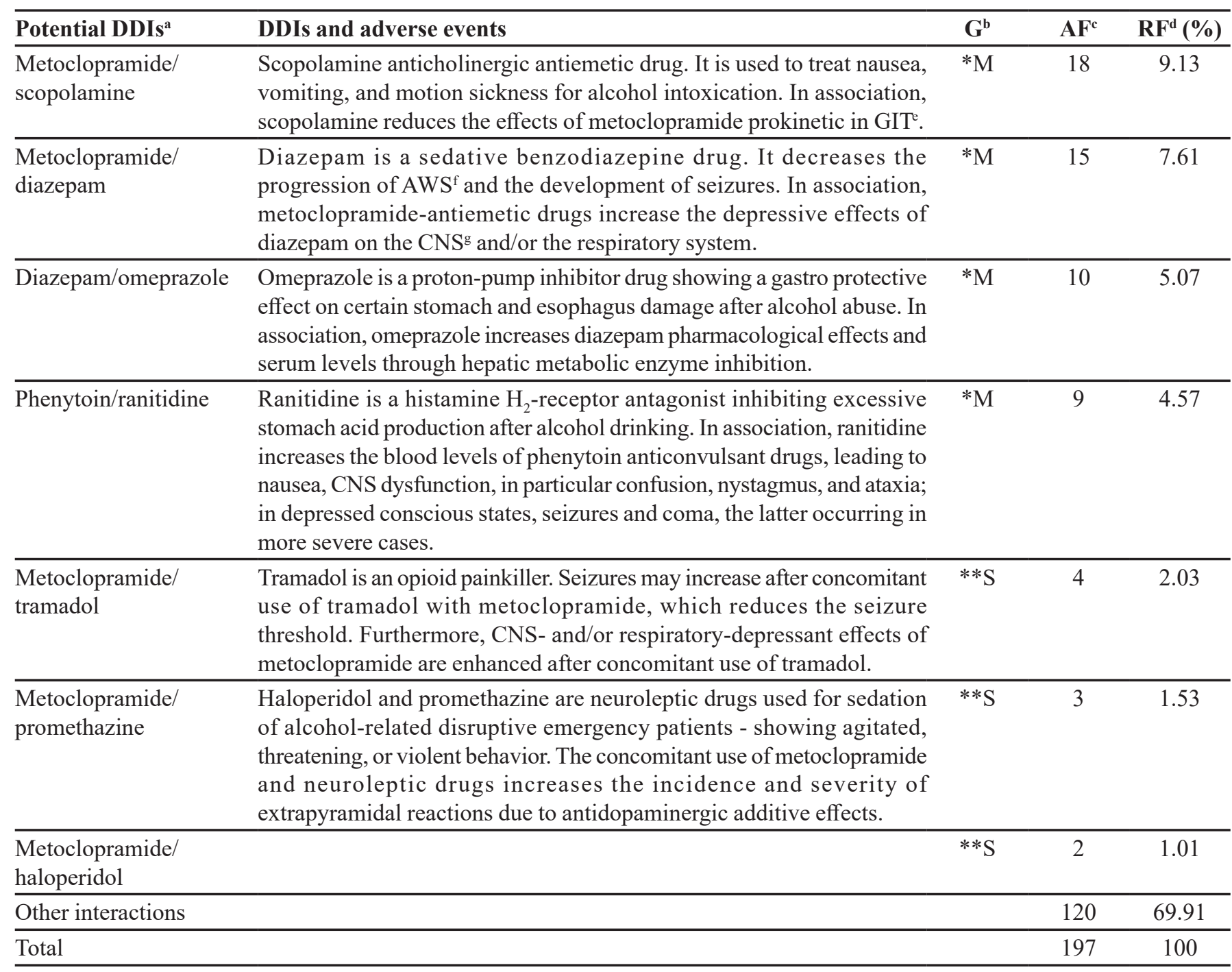

${ }^{\mathrm{a} D D I s}$, Dug-Drug Interactions; ${ }_{\mathrm{b}}^{\mathrm{b}} \mathrm{G}$, Gravity; ${ }^{\mathrm{c}} \mathrm{AF}$, Absolute Frequency (n); ${ }^{\mathrm{d}} \mathrm{RF}$, Relative Frequency (\%); ${ }^{\mathrm{e}} \mathrm{GIT}$, Gastrointestinal Tract; ${ }_{\mathrm{f}}^{\mathrm{A} W S}$, Alcohol Withdrawal Syndrome; ${ }^{\mathrm{g}} \mathrm{CNS}$, Central Nervous System. *M, Moderate; **S, Severe.

different mechanisms and the clinical consequences are bilateral, i.e. alcohol can interfere with drug clinical events and vice versa (Fraser, 1997).

As observed in DDIs, metoclopramide was involved in the majority of drug-alcohol interactions (75\% possible interactions) (Table IV). Another important association is alcohol and psychoactive drugs.

Similar to alcohol, many of these psychoactive drugs are central nervous system depressants. They increase the potential risk of moderate and severe pharmacodynamic interactions showing severe consequences for the physiological system (e.g., cumulative narcosis) (Vonbach et al., 2008).

Therefore, the use of psychoactive drugs for the management of anxiety, agitation and/or aggression, typical adverse events resulting from acute alcohol poisoning, requires a thorough control in pharmacotherapy and clinical monitoring of patients in emergency hospitalmedical care.

As shown in Table IV, the drugs used in hospitalmedical care of acute alcohol poisoning cases may directly or indirectly influence several alcohol pharmacokinetics parameters (e.g., absorption, bioavailability and biotransformation), including toxic alcohol metabolite formation (acetaldehyde).

On the other hand, alcohol may directly influence the hepatic metabolism of several drugs commonly used in acute alcohol poisoning emergency treatment. 
TABLE IV - Gravity, frequency, interaction mechanisms and possible adverse events of major potential drug-alcohol interactions in acute alcohol intoxication emergency hospital-medical care. Sergipe, January 2009 to July 2011

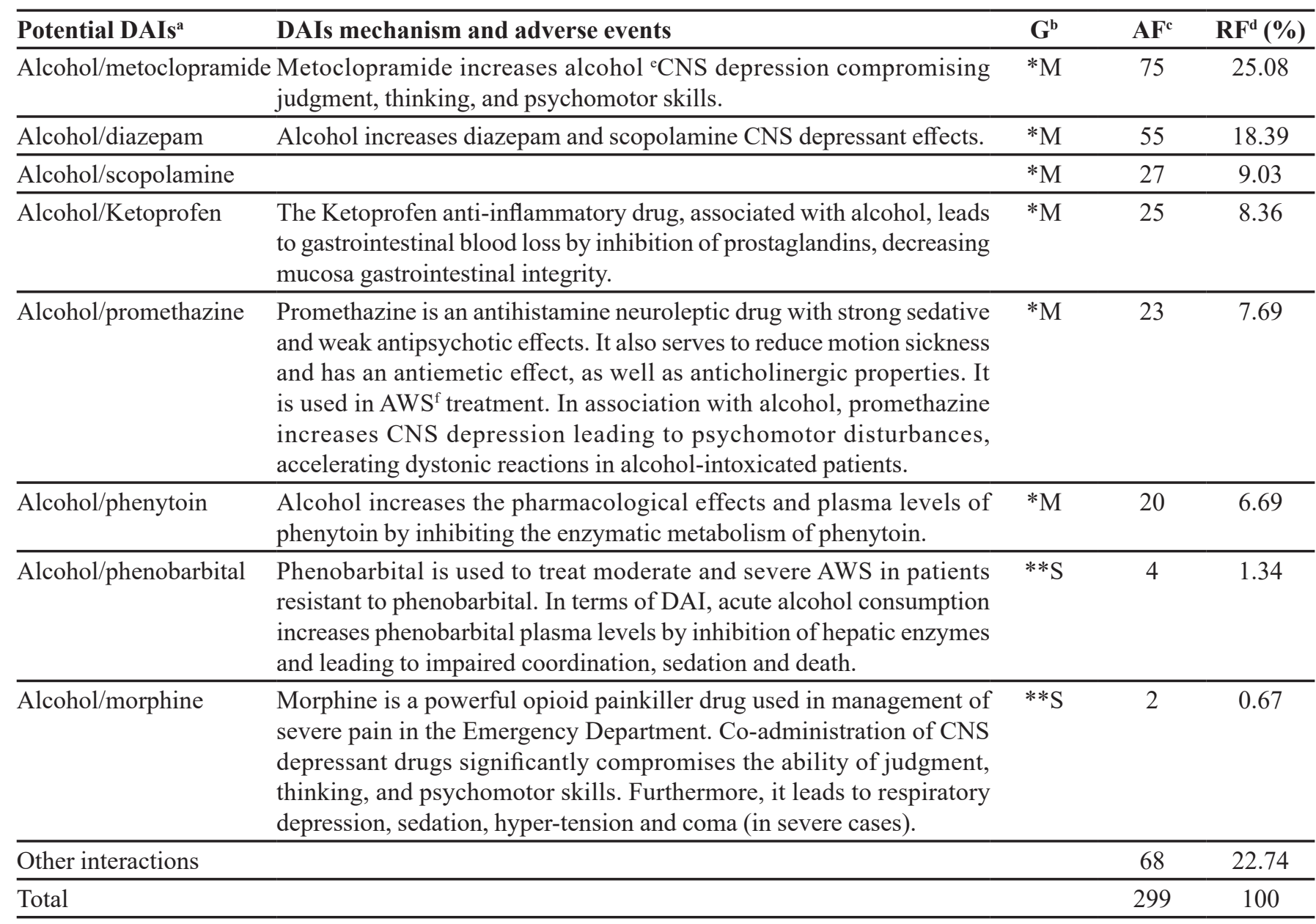

${ }^{a}$ DAIs, Dug-Alcohol Interactions; ${ }^{\mathrm{b}} \mathrm{G}$, Gravity; ${ }^{\mathrm{c}} \mathrm{AF}$, Absolute Frequency (n); ${ }^{\mathrm{d}} \mathrm{RF}$, Relative Frequency (\%); ${ }^{\mathrm{e}} \mathrm{CNS}$, Central Nervous System; ${ }^{\mathrm{f} A W S}$, Alcohol Withdrawal Syndrome. *M, Moderate; **S, Severe.

While prolonged use of lower doses of alcohol (i.e., chronic intake) induce metabolism liver enzymes' (CYP2E1) decreasing of plasma half-life $\left(\mathrm{t}_{1 / 2}\right)$ with certain drugs, high doses of alcohol (e.g., binge drinking) compete for drug metabolism liver enzymes increasing plasma half-life $\left(\mathrm{t}_{1 / 2}\right)$ for these drugs (Table IV) (Schuckit, 2011).

In these cases, considering that some drugs prescribed for acute alcohol poisoning emergency hospitalmedical care are extremely toxic even at low doses (narrow therapeutic window drugs) or show high potential risk of ADI, any change in drug plasma concentration can lead to severe clinical complications in patients.

In order to enhance pharmacotherapeutic effectiveness and ensure safety in the emergency department, some suggestions could be: (i) dose adjustment, (ii) change in administration time, (iii) reduction in the number and/ or suspension of some drugs and, (iv) their replacement by others that have a mild risk of drug interactions with alcohol and other drugs used in pharmacotherapy.

Our research contributed to the identification of potentially dangerous alcohol intoxication scenarios and susceptible binge drinking groups, as well as to the clarification of chemical substances involved in alcoholic poisoning.

Furthermore, this study has enabled us to describe the gravity of the frequency of ADIs in the emergency department. The potential risks described above show the lack of preparation in hospital teams in relation to the drug interaction issue, during routine hospital-medical care of patients intoxicated by alcohol.

The description of the population profile alongside ADIs in the emergency room has contributed to health surveillance, as well as to evidence-based public health strategies, policy measures and effective interventions on a broader scale. 
Despite current public health policy discouraging binge drinking in the country, the data demonstrate a high consumption in the studied population. The measurement of possible drug interactions aims to contribute to the prevention of potential clinical complications in hospitalmedical care of alcohol misuse disorders. Thus, a thorough review on pharmacotherapy of these individuals must be introduced to ED clinical staff to reduce the prescription of drugs that have the potential to cause adverse interactions.

\section{ACKNOWLEDGMENTS}

The article's research received grant support, in part, by the Sergipe State Research Support and Technological Innovation Foundation ([FAPITEC]) and the Brazilian Council for Scientific and Technological Development (CNPq).

The authors are grateful to the coordinator of CEATOX-SE, Antônio Medeiros Venâncio.

\section{REFERENCES}

AMERICAN PSYCHIATRIC ASSOCIATION. Practice guidelines for the treatment of patients with substance use psychiatric disorders, second edition. In:

(Org.). Practice guideline for the treatment of psychiatric disorders: compendium 2006. 2.ed. Arlington: American Psychiatric Association, 2006. p.291-564.

BATES, D.W.; SPELL, N.; CULLEN, D.J.; BURDICK, E.; LAIRD, N.; PETERSEN, L.A.; SMALL, S.D.; SWEITZER, B.J.; LEAPE, L.L.; ADVERSE DRUG EVENTS PREVENTION STUDY GROUP. The costs of adverse drug events in hospitalized patients. JAMA, v.277, p.307-311, 1997.

BOSCH, M.E.; RAMOS, B.S.; NAVARRO, M.V.G.; RUBIO, M.D.S.; GIL, R.M.; LINAZA, P.V. Prevalence of drug interactions in hospital healthcare. Int. J. Clin. Pharm., v.34, p.807-817, 2012.

BRASIL. Ministério da Saúde. Secretaria de Atenção à Saúde. Departamento de Ações Programáticas Estratégicas. Álcool e redução de danos: uma abordagem inovadora para países em transição. Brasília: Ministério da Saúde, 2004. 144p. (Série F: Comunicação e Educação em Saúde).

CARLSON, R.W.; KUMAR, N.N.; MCKINSTRY, E.W.; PURI, S.A.N.; JACKSONA, F.K.; SHASHIKUMAR, S. Alcohol withdrawal syndrome. Crit Care Clin., v.28, p.549-585, 2012.
CURRIER, G.W.; JAGODA, A.S. Clinical policy: critical issues in the diagnosis and management of the adult psychiatric patient in the emergency department. Ann. Emerg. Med., v.47, p.79-99, 2006.

DETTLING, A.; SKOPP, G.; GRAW, A.; HAFFNER, H.T. The influence of sex hormones on the elimination kinetics of ethanol. Forensic Sci. Int., v.177, p.85-89, 2008.

DRUGS.COM. Drug Interactions Checker. Available at: $<\mathrm{http}: / /$ www.drugs.com/drug_interactions.html $>$. Accessed on: Oct. 2014.

FULTON, M.M.; ALLEN, E.R. Polypharmacy in the elderly: a literature review. J. Am. Acad. Nurse Pract., v.17, 123132, 2005.

FRASER, A.G. Pharmacokinetic interactions between alcohol and other drugs. Clin. Pharmacokinet., v.33, p.79-90, 1997.

GUDIN, J.A.; MOGALI, S.; JONES, J.D.; COMER, S.D. Risks, management, and monitoring of combination opioid, benzodiazepines, and/or alcohol use. Postgrad. Med., v.125, p.115-130, 2013.

HEININGER-ROTHBUCHER, D.; BISCHINGER, S.; ULMER, H.; PECHLANER, C.; SPEER, G.; WIEDERMANN, C. Incidence and risk of potential adverse drug interactions in the emergency room. Resuscitation, v.49, p.283-288, 2001.

HUSSAR, D.A. Drug interactions. In: REMINGTON: the science and practice of pharmacy. 20.ed. Baltimore: Lippincott Willians \& Wilkins, 2000. p.1746-1761.

INSTITUTO BRASILEIRO DE GEOGRAFIA E ESTATÍSTICA. IBGE. Available at: <http://www.ibge. gov.br>. Accessed on: Oct. 2014.

LUKENS, T.W.; WOLF, S.J.; EDLOW, J.A.; SHAHABUDDIN, S.; ALLEN, M.H.; MALLET, L.; SPINEWINE, A.; HUANG, A. The challenge of managing drug interactions in elderly people. Lancet, v.370, p.185-191, 2007.

MILLER, P.; PLANT, M.; PLANT, M. Spreading out or concentrating weekly consumption: alcohol problems and other consequences within a UK population sample. Alcohol Alcoholism, v.40, p.461-468, 2005. 
NAIMI, T.S.; BREWER, R.D.; MOKDAD, A.; DENNY, C.; SERDULA, M.K.; MARKS, J.S. Binge drinking among US adults. JAMA, v.289, p.70-77, 2003.

NANCHAHAL, K.; ASHTON, W.D.; WOOD, D.A. Alcohol consumption, metabolic cardiovascular risk factors and hypertension in women. Int. J. Epidemiol., v.29, p.57-64, 2000.

REHM, J.; GREENFIELD, T.K.; WALSH, G.; XIE, X.; ROBSON, L.; SINGLE, E. Assessment methods for alcohol consumption, prevalence of high risk drinking and harm: a sensitivity analysis. Int. J. Epidemiol., v.28, p.219-224, 1999.

ROIZEN, J. An overview of epidemiological emergency room studies of injury and alcohol. In: CHERPITEL, C.J.; BORGES, G.; GIESBRECHT, N., eds. Alcohol and injuries: emergency department studies in an international perspective. Geneva: Would Health Organization, 2009. cap.5, p.55-95.

SEGATTO, M.L.; PINSKY, I.; LARANJEIRA, R.; REZENDE, F.F.; VILELA, T.R. Screening and brief intervention for alcoholic patients treated at emergency rooms: prospects and challenges. Cad. Saúde Pública, v.23, p.1753-1762, 2007.

SCHUCKIT, M.A. Ethanol and methanol. In: BRUNTON, L.; CHABNER, B.; KNOLLMAN, B., (Eds.). Goodman \& Gilman's: the pharmacological basis of therapeutics. 12.ed. New York: Mc Graw-Hill Medical, 2011. cap.23, p.629-648.

SHAW, J.; HUNT, I.M.; FLYNN, S.; AMOS, T.; MEEHAN, J.; ROBINSON, J.; BICKLEY, H.; PARSONS, R.; MCCANN, K.; BURNS, J.; KAPUR, N.; APPLEBY, L. The role of alcohol and drugs in homicides in England and Wales. Addiction, v.101, p.1117-1124, 2006.
SISTEMA NACIONAL DE INFORMAÇÕES TÓXICO FARMACOLÓGICAS. 2011. Available at: <http://www. fiocruz.br/sinitox $>$. Accessed on: Oct. 2014.

UNITED NATION OFFICE ON DRUGS AND CRIME. World Drug Report 2013. New York: United Nations, 2013. 115p. Available at: https://www.unodc.org/unodc/secured/wdr/ wdr2013/World_Drug_Report_2013.pdf $>$. Accessed on: Oct. 2014.

VONBACH, P.; DUBIED, A.; KRÄHENBÜH, S.; BEER, J.H. Prevalence of drug-drug interactions at hospital entry and during hospital stay of patients in internal medicine. Eur. $J$. Intern. Med., v.19, p.413-420, 2008.

WILSNACK, R.W.; VOGELTANZ, N.D.; WILSNACK, S.C.; HARRIS, T.R. Gender differences in alcohol consumption and adverse drinking consequences: cross-cultural patterns. Addiction, v.95, p.251-265, 2000.

WORLD HEALTH ORGANIZATION. Statistical presentation. In:__. International Statistical classification of diseases and related health problems. 10.ed. Geneva: WHO, 2010. cap.5, p.147-162. (ICD-10). Available at: $<$ http:// www.who.int/classifications/icd/ICD10Volume2_en_2010. pdf $>$. Accessed on: Oct. 2014.

YE, Y.; CHERPITEL, C.J. Risk of injury associated with alcohol and alcohol-related injury. In: CHERPITEL, C.J.; BORGES, G.; GIESBRECHT, N., (Eds.). Alcohol and injuries: emergency department studies in an international perspective. Geneva: Would Health Organization, 2009. cap.1, p.3-15.

Received for publication on $22^{\text {nd }}$ October 2014 Accepted for publication on $1^{\text {st }}$ September 2015 
